\title{
Dietary factors affecting the maximum feed intake and the body composition of pre-ruminant kid goats of the Granadina breed
}

\author{
BY M. R. SANZ SAMPELAYO, L. ALLEGRETTI, I. RUIZ MARISCAL, \\ F. GIL EXTREMERA AND J. BOZA \\ Estación Experimental del Zaidin (Consejo Superior de Investigaciones Cientificas), Departamento \\ de Nutrición Animal, Profesor Albareda 1, 18008 Granada, Spain
}

(Received 28 February 1994 - Revised 15 December 1994 - Accepted 16 January 1995)

\begin{abstract}
An experiment was carried out with kid goats of the Granadina breed to identify the dietary factors affecting voluntary feed intake of the kid goat and those that additively could determine its body composition. The animals used were from birth to $61 \mathrm{~d}$ of age, fed ad lib. on different milk replacers containing 200, 240 and $280 \mathrm{~g}$ crude protein $/ \mathrm{kg} \mathrm{DM}$ and 200, 240 and $280 \mathrm{~g}$ fat $/ \mathrm{kg} \mathrm{DM}$, thus giving nine dietary treatments. The utilization of the milk replacers and the animals' body composition were determined by balance and slaughter trials. There were significant positive effects of protein concentration of the milk replacers on component digestibilities, energy metabolizability, feed intake, empty-body weights, empty-body composition and protein and fat retention. The concentration of fat in the milk replacers also had a significant positive effect on the digestible and metabolizable energy concentration of the diets and on fat retention. The relationships existing between feed intake and diet composition (concentration of digestible protein, metabolizable energy and digestible protein:metabolizable energy ratio) as well as between empty-body composition or protein and fat retention and diet composition, were examined. From these it was deduced that feed intake was significantly influenced by the digestible protein concentration of the diets. The higher the digestible protein concentration the higher the feed intake up to a maximum digestible protein concentration value. As the digestible protein concentration of the diets was the dietary factor which significantly influenced feed intake, this also significantly influenced the body composition and the protein and fat retention. The protein concentration of the feed at which metabolizable energy intake in these animals would be greatest was estimated to be $347 \mathrm{~g} / \mathrm{kg}$ DM.
\end{abstract}

Feed composition: Feed intake: Body composition: Kid goats

The low voluntary feed intake of pre-ruminant animals explains why from birth until 30-35 d of age their body composition is determined more by their weight than by their feed intake (Walker, 1986). In this context, the maximum feed intake of the kid goat has been found to be low in comparison with other pre-ruminants. Sanz Sampelayo et al $(1990 \mathrm{~b})$ reported that for the first month of life, empty-body composition of kids depended on empty-body weight, independently of intake level and even of dietary regimen. However, in older or heavier kids, which are those considered ideal for slaughter, results indicate that the dietary regimen and level of feed intake do have some effect on the body composition (Bas \& Morand-Fehr, 1987; Bas et al. 1987, 1992; Lara, 1991). Because of this, and because the typical development of caprine species gives rise to very lean carcasses (Morand-Fehr et al. 1985), different studies were conducted by feeding individuals of different breeds with milk replacers differing in their fat concentrations (Bas \& Morand-Fehr, 1987; Bas et al. 1987; Lara, 1991). In all cases the responses to the different levels of fat were very weak and much lower than expected, which in the opinion of Lara (1991) could be due to the low levels of voluntary feed intake generally recorded. With this in mind, and with the objective 
of obtaining a better system for artificially milk-feeding the pre-ruminant kid to achieve a satisfactory body composition, a study was designed to analyse the dietary factors affecting voluntary feed intake of the kid goat and those that additively could determine its body composition. In the present study these aspects were analysed using milk replacers differing in their protein and fat concentrations. The effect of treatment on feed intake, digestibility of the nutrients, digestible protein and metabolizable energy concentrations and digestible protein:metabolizable energy ratio in the diets, and on body composition were analysed. The relationships between feed intake or empty-body composition and digestible protein concentration, metabolizable energy concentration and digestible protein:metabolizable energy ratio in the diets were also established.

\section{MATERIALS AND METHODS \\ Animals and experimental design}

Forty-two male kid goats of the Granadina breed were used. These were separated from their dams when they were $2 \mathrm{~d}$ old. Then an initial slaughter group of six animals was killed while the remaining thirty-six were kept individually under the experimental conditions until they were $61 \mathrm{~d}$ old. The experiment was designed in a completely randomized $3 \times 3$ factorial arrangement. Treatments consisted of three concentrations of crude protein in the milk replacer (low (L): $200 \mathrm{~g} / \mathrm{kg} \mathrm{DM}$, medium (M): $240 \mathrm{~g} / \mathrm{kg} \mathrm{DM}$ and high (H): $280 \mathrm{~g} / \mathrm{kg}$ $\mathrm{DM}$ ) and three concentrations of fat in the milk replacer $(\mathrm{L}: 200 \mathrm{~g} / \mathrm{kg} \mathrm{DM}, \mathrm{M}: 240 \mathrm{~g} / \mathrm{kg}$ DM and $\mathrm{H}: 280 \mathrm{~g} / \mathrm{kg} \mathrm{DM}$ ). Four animals were allocated at random to each treatment.

\section{Experimental procedure}

Animals were housed in individual cages in an animal house maintained at a temperature of $24 \pm 2^{\circ}$ and a relative humidity of $60 \pm 5 \%$. During the first $4 \mathrm{~d}$ of life all the animals consumed colostrum $a d$ lib. and, thereafter, one of the nine milk replacers until they were $60 \mathrm{~d}$ old. In order to assess the effect of replacer composition on voluntary feed intake, animals had $a d$ lib. access daily from 09.00 until 18.00 hours. The replacers were prepared at $170 \mathrm{~g}$ fresh powder $/ \mathrm{kg}$ and were offered in containers fitted with teats. The containers were placed over a device designed to maintain the replacer temperature at $39 \pm 2^{\circ}$ and to keep it satisfactorily mixed (Ruiz Mariscal et al. 1990). Because kid goats are very sensitive to cold, the milk replacer temperature was maintained at body temperature which also helped to prevent the separation of the fat. The protein component of the milk replacers was obtained from three different protein sources: spray-dried skimmed milk powder, soyabean micronized for milk replacer, and casein $(50: 25: 25 \mathrm{w} / \mathrm{w})$. To bring the methionine and lysine contents up to those recommended for pre-ruminants (Walker, 1973; PatureauMirand, 1975; Williams \& Hewitt, 1979) further quantities of these two amino acids were added separately. To satisfy requirements for $\mathrm{Ca}$ and $\mathrm{P}$ (Sanz Sampelayo et al. 1987), $\mathrm{CaHPO}_{4} \cdot 2 \mathrm{H}_{2} \mathrm{O}$ and $\mathrm{CaCO}_{3}$ were added. $\mathrm{NaCl}$ and a mineral-vitamin supplement (Auromix Milk, Cyanamid Iberica, Madrid, Spain) were included in all replacers. The fat component of the replacers was obtained from purified pork lard. After melting the lard in a water bath, it was incorporated into the diets by homogenization using a mechanical mixer. To stabilize the emulsion, two emulsifiers were added (Keltrol F., Vedegsa, Barcelona, Spain and Tween 80, Acofar, Barcelona, Spain). Glucose was included in the nine replacers in different quantities to balance the remaining ingredients. To reduce bacterial growth and digestive disorders the replacers were acidified to $3 \mathrm{ml} / 1$ with lactic acid, as proposed by Havrevoll et al. (1991). In relation to the nutritional utilization and the performance of animals, protein, fat and carbohydrate sources employed are considered 
Table 1. Ingredients $(\mathrm{g} / \mathrm{kg} D M)$ and gross energy concentration $(M J / \mathrm{kg} D M)$ of the milk replacers

\begin{tabular}{|c|c|c|c|c|c|c|c|c|c|}
\hline \multirow{2}{*}{$\begin{array}{l}\text { Protein concentration ... } \\
\text { Fat concentration... }\end{array}$} & \multicolumn{3}{|c|}{$\mathbf{H}$} & \multicolumn{3}{|c|}{$\mathbf{M}$} & \multicolumn{3}{|c|}{$\mathrm{L}$} \\
\hline & $\mathrm{H}$ & $\mathrm{M}$ & L & $\mathrm{H}$ & $\mathrm{M}$ & L & $\mathrm{H}$ & $\mathrm{M}$ & $\mathrm{L}$ \\
\hline \multicolumn{10}{|l|}{ Ingredient } \\
\hline Skimmed milk & 394.6 & 394.6 & 394.6 & $339 \cdot 7$ & 339.7 & $339 \cdot 7$ & $284 \cdot 8$ & 284.8 & $284 \cdot 8$ \\
\hline Micronized soyabean & $133 \cdot 8$ & 133.8 & 133.8 & $114 \cdot 8$ & 114.8 & 114.8 & $95 \cdot 8$ & $95 \cdot 8$ & $95 \cdot 8$ \\
\hline Casein & $72 \cdot 7$ & $72 \cdot 7$ & $72 \cdot 7$ & $62 \cdot 3$ & $62 \cdot 3$ & $62 \cdot 3$ & 51.9 & 51.9 & 51.9 \\
\hline Pork lard & 275.9 & $238 \cdot 0$ & 196.5 & 276.8 & 238.9 & 197.2 & 277.7 & $239 \cdot 8$ & $198 \cdot 1$ \\
\hline Glucose & $59 \cdot 6$ & 97.5 & $139 \cdot 2$ & 138.8 & 176.7 & 218.4 & 220.1 & $258 \cdot 0$ & 299.7 \\
\hline Mineral-vitamin mix & $19 \cdot 3$ & $19 \cdot 3$ & $19 \cdot 3$ & $19 \cdot 3$ & $19 \cdot 3$ & $19 \cdot 3$ & $19 \cdot 3$ & $19 \cdot 3$ & $19 \cdot 3$ \\
\hline Sodium chloride & 14.5 & 14.5 & 14.5 & $14 \cdot 5$ & $14 \cdot 5$ & $14 \cdot 5$ & $14 \cdot 5$ & $14 \cdot 5$ & 14.5 \\
\hline Dicalcium phosphate & $14 \cdot 5$ & 14.5 & $14 \cdot 5$ & $19 \cdot 4$ & $19 \cdot 4$ & $19 \cdot 4$ & $22 \cdot 2$ & $22 \cdot 2$ & $22 \cdot 2$ \\
\hline Calcium carbonate & $9 \cdot 7$ & $9 \cdot 7$ & $9 \cdot 7$ & $9 \cdot 7$ & $9 \cdot 7$ & $9 \cdot 7$ & $9 \cdot 7$ & $9 \cdot 7$ & $9 \cdot 7$ \\
\hline Lysine & $2 \cdot 9$ & $2 \cdot 9$ & $2 \cdot 9$ & $2 \cdot 5$ & $2 \cdot 5$ & $2 \cdot 5$ & $2 \cdot 1$ & $2 \cdot 1$ & $2 \cdot 1$ \\
\hline Methionine & $2 \cdot 5$ & $2 \cdot 5$ & $2 \cdot 5$ & $2 \cdot 2$ & $2 \cdot 2$ & $2 \cdot 2$ & 1.9 & 1.9 & 1.9 \\
\hline Gross energy & $23 \cdot 9$ & $23 \cdot 2$ & $22 \cdot 1$ & $23 \cdot 4$ & $22 \cdot 5$ & $21 \cdot 4$ & $23 \cdot 3$ & $22 \cdot 3$ & 21.2 \\
\hline
\end{tabular}

$\mathrm{H}$, high (280 g/kg DM); M, medium (240 g/kg DM); L, low (200 g/kg DM).

adequate for pre-ruminant milk replacers (Soliman et al. 1979; Ørskov, 1982; Moulin, 1983). The ingredient composition of the diets and their gross energy concentration are shown in Table 1.

All animals were weighed every $3 \mathrm{~d}$. Three balance trials of $8 \mathrm{~d}$ duration were performed, starting when the animals were aged 23,38 and $53 \mathrm{~d}$ respectively. During these trials total faeces and urine collections were made and samples were stored frozen. From the bulked samples, subsamples were taken for the determination of DM, N and energy contents of the urine, and DM, N, fat and energy contents of the faeces. The protein, fat and energy digestibilities and the energy metabolizability were calculated for each animal. The digestible protein (DP; g/ kg DM), digestible energy (DE; MJ $/ \mathrm{kg} \mathrm{DM}$ ) and metabolizable energy (ME; $\mathrm{MJ} / \mathrm{kg} \mathrm{DM}$ ) concentrations of the diets as well as the corresponding DP:ME ratios $(\mathrm{g} / \mathrm{MJ})$ were also calculated, as were the $\mathrm{DM}$ intakes $\left(\mathrm{DMI} ; \mathrm{g} / \mathrm{kg}^{\mathbf{6} \cdot 75}\right.$ per d) and $\mathrm{ME}$ intakes (MEI; $\mathrm{kJ} / \mathrm{kg}^{0 \cdot 75}$ per $\mathrm{d}$ ). The day after the end of the final balance period, when the animals were aged $61 \mathrm{~d}$, they were slaughtered by carotid section after anaesthetization using an intramuscular injection of Xylazine (Rompun, Bayer, Barcelona, Spain). Once the animals were dead and completely bled, the skin, limbs, internal organs and head were removed. The rumen, ieticulum, omasum and abomasum were washed of their contents. The blood, skin, alimentary canal, all internal organs and the carcass were considered as distinct body parts and were minced separately. Empty-body-weight values (EBW; kg) and composition, i.e., DM, protein, fat (g/ kg EBW) and energy $(\mathrm{MJ} / \mathrm{kg} \mathrm{EBW})$ were calculated. Finally, from the body composition of animals slaughtered at birth and at $61 \mathrm{~d}$ of age, protein retention and fat retention rates $\left(\mathrm{g} / \mathrm{kg}^{\mathbf{0} 75}\right.$ per $\left.\mathrm{d}\right)$ were also calculated.

$\mathrm{DM}$ and $\mathrm{N}$ analyses were performed on samples of the freshly minced parts. All other determinations were carried out on lyophilized samples. $\mathrm{N}$ was determined by the Kjeldahl method and energy using an adiabatic bomb calorimeter. The fat concentration of the different milk replacers was analysed by the Gerber method (Pearson, 1976), that of the faeces by extraction with petroleum ether (boiling point $40-60^{\circ}$ ) after $\mathrm{HCl}$ hydrolysis and that of the different body parts by extraction with chloroform-methanol $(2: 1, \mathrm{v} / \mathrm{v})$. 


\section{Statistical analysis}

The effect of protein and fat concentrations in the milk replacers on various aspects of milk replacer intake and utilization, empty-body composition, and fat and protein deposition rates were analysed by the least squares ANOVA method (Steel \& Torrie, 1984), using a model with two main effects (protein concentration and fat concentration in the milk replacer) and their interaction. The birth weight was used as covariance factor to analyse the effect of protein and fat concentrations in the milk replacer on the empty-body weights achieved by the animals at the end of the experiment. In the same way, the empty-body weight was used as covariance factor to analyse the effect of protein and fat concentrations in the milk replacer on empty-body composition. Finally, the relationships existing between feed intake, empty-body composition or protein and fat deposition rates and DP concentration, ME concentration and DP:ME ratio in the diets, were analysed by multiple regression techniques. For this, the results were analysed using the Statgraphics statistical package (Statgraphics, 1991; regression analysis, stepwise variable selection method), after examining the data for possible collinearity existing between the considered independent variables (Aziz \& Sharaby, 1993).

\section{RESULTS}

Effect of treatment on component digestibilities, energy metabolizability and intakes The effects of different concentrations of protein and fat in the milk replacers on component digestibilities, energy metabolizability, DP, DE and ME concentrations and DP:ME ratios in the diets, and on DM and ME intakes are shown in Table 2. There were no significant interactions $(P>0.05)$ in any of the analyses and so only main effects are reported. As the concentration of protein increased, the values for all these variables also increased and this effect was always significant. The increasing concentration of fat significantly reduced the energy digestibility and metabolizability values but increased the $\mathrm{DE}$ and $\mathrm{ME}$ concentrations of the diets.

\section{Effect of treatment on empty-body-weight values, empty-body composition and protein and fat deposition rates}

The effects of the protein and fat concentrations of the milk replacers on the empty-body weights and on the contribution of DM, protein, fat and energy to these weights as well as on the protein and fat deposition rates are shown in Table 3 . There were no significant interactions $(P>0.05)$ in any of the analyses so only main effects are reported. Raising the protein concentration in the feed significantly increased the empty-body weights and their DM, fat and energy concentrations as well as the protein and fat deposition rates but protein concentration in empty-body weight was not affected. The concentration of fat had a significant effect only on the fat deposition rates.

\section{Effects of milk replacer composition on DM and $M E$ intakes}

The relationships between DMI $\left(\mathrm{g} / \mathrm{kg}^{0.75}\right.$ per d) or MEI $\left(\mathrm{kJ} / \mathrm{kg}^{0.75}\right.$ per d) and the composition of the diet (DP concentration ( $\mathrm{g} / \mathrm{kg} / \mathrm{DM}), \mathrm{ME}$ concentration $(\mathrm{MJ} / \mathrm{kg} \mathrm{DM})$ and DP:ME ratio ( $\mathrm{g} / \mathrm{MJ})$ ) were established by multiple regression analysis. The linear and quadratic effects of the variables as well as their interactions were examined. When according to the corresponding confidence interval the intercept was not significantly $(P>$ $0.05)$ different from zero, the equation was re-calculated with the intercept forced through zero. The best equations (minimum residual standard deviation, RSD) with significant $(P<$ 0.05 ) terms that were obtained in this way, were:

$$
\mathrm{DMI}=0.44(\mathrm{SE} 0.02) \mathrm{DP}-0.00076(\mathrm{SE} 0.00008) \mathrm{DP}^{2}
$$


FEED INTAKE AND BODY COMPOSITION IN KID GOATS
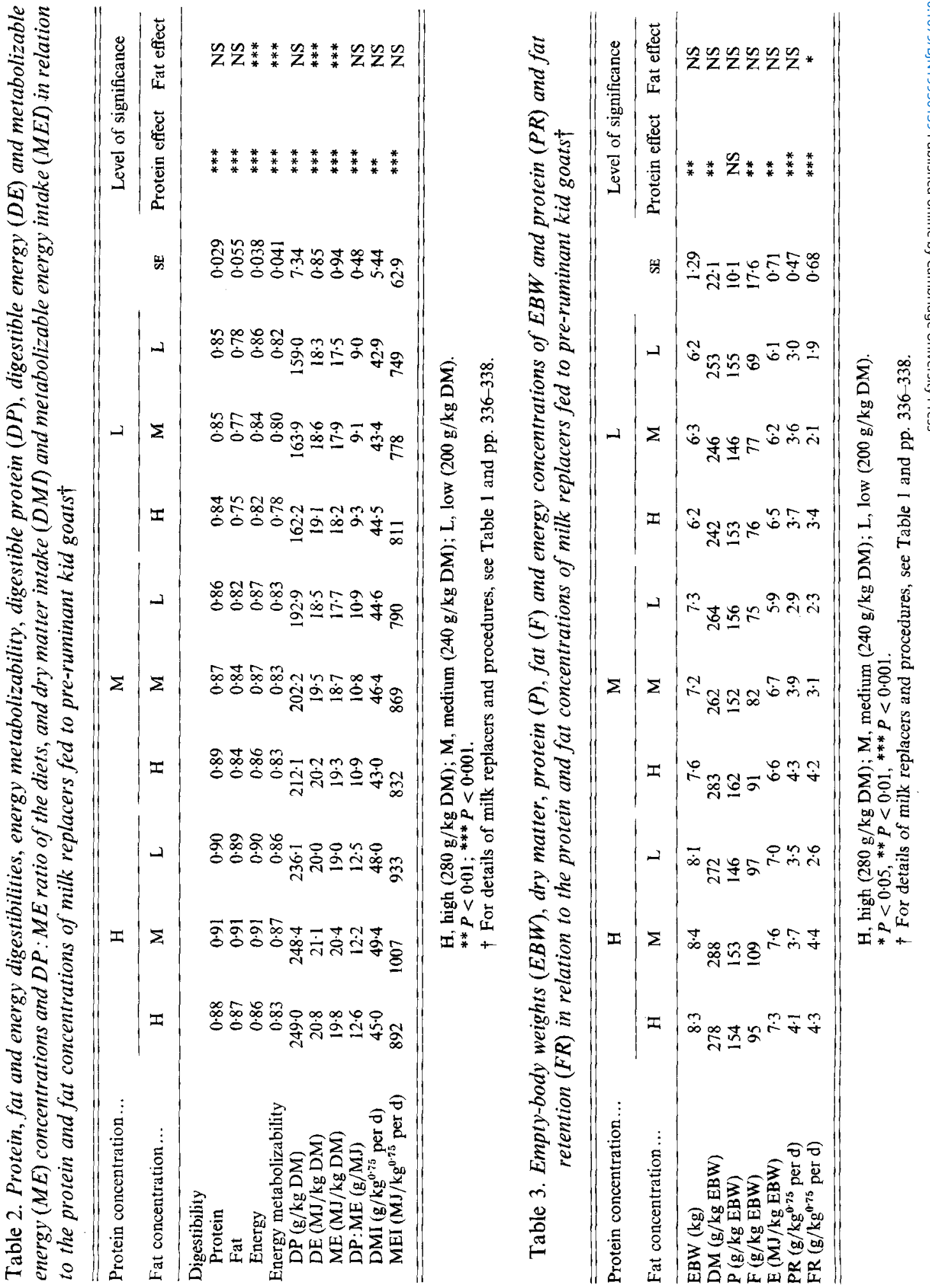
( $R^{2} 0.985$; RSD 5.57; level of significance of DP: $P<0.001$; level of significance of $\mathrm{DP}^{2}$ : $P<0.001)$.

$$
\mathrm{MEI}=6.15(\mathrm{SE} 0.34) \mathrm{DP}-0.0094(\mathrm{SE} 0.0016) \mathrm{DP}^{2}
$$

( $R^{2} 0.984$; RSD 108.8; level of significance of DP: $P<0.001$; level of significance of DP ${ }^{2}$ : $P<0.001$.

From these results it can be concluded that the DMI or the MEI by these animals increases with increasing DP concentration of the diets but at a reducing rate to reach a maximum at $290 \mathrm{~g} \mathrm{DP} / \mathrm{kg} \mathrm{DM}$ for DMI and $327 \mathrm{~g} \mathrm{DP} / \mathrm{kg}$ DM for MEI.

\section{Effects of milk replacer compositions on empty-body-weight composition and on protein and fat deposition rates}

The relationships between the composition of the EBW of the animals: DM concentration ( $\mathrm{g} / \mathrm{kg}$ EBW), protein concentration $(\mathrm{P} ; \mathrm{g} / \mathrm{kg}$ EBW), fat concentration $(\mathrm{F} ; \mathrm{g} / \mathrm{kg}$ EBW) and energy concentration ( $\mathrm{E} ; \mathrm{MJ} / \mathrm{kg} \mathrm{EBW})$ ) or protein retention rate $\left(\mathrm{PR} ; \mathrm{g} / \mathrm{kg}^{\mathbf{7 7 5}}\right.$ per d) and fat retention rate (FR; $\mathrm{g} / \mathrm{kg}^{0.75}$ per d) and the composition of the diet (DP concentration (g/kg DM), ME concentration (MJ/kg DM) and DP:ME ratio $(\mathrm{g} / \mathrm{MJ})$ were established by multiple regression analysis. The linear and quadratic effects of the variables as well as their interaction were examined. When according to the corresponding confidence interval the intercept was not significantly different from zero, the equation was re-calculated with the intercept forced through zero. The best equations (minimum RSD) with significant terms that were obtained in this way, were:

(a) Body composition

$$
\mathrm{DM}=2 \cdot 24 \text { (SE 0.11) DP-0.0045 (SE 0.0005) DP² }
$$

$\left(R^{2} 0.994\right.$; RSD 20.86; level of significance of DP: $P<0.001$; level of significance of DP2: $P<0.001)$.

$$
\mathrm{F}=0.42(\mathrm{SE} 0.01) \mathrm{DP}
$$

$\left(R^{2} 0.966\right.$; RSD 16.56 ; level of significance of DP: $\left.P<0.001\right)$.

$$
\mathrm{E}=0.052(\text { SE 0.004) DP }-0.00009 \text { (SE 0.00002) DP2 }
$$

$\left(R^{2} 0.990 ;\right.$ RSD 0.70 ; level of significance of DP: $P<0.001$; level of significance of DP2: $P<0.001)$.

(b) Protein and fat retention

$$
\mathrm{PR}=0.025 \text { (SE 0.003) DP - 0.000033 (SE 0.000012) DP }{ }^{2}
$$

$\left(R^{2} 0.984\right.$; RSD 0.46 ; level of significance of DP: $P<0.001$; level of significance of DP2: $P<0.001)$.

$$
\mathrm{FR}=0.0145 \text { (SE 0.0006) DP }
$$

$\left(R^{2} 0.947\right.$; RSD 0.71 ; level of significance of DP: $\left.P<0.001\right)$.

These results show, except in the case of the protein concentration of the empty-body weight, that the DP concentration of the feed was the dietary factor that was most closely correlated with body composition as well as with protein and fat retention. 


\section{DISCUSSION}

\section{Effect of treatment on component digestibilities, energy metabolizability and intakes}

The protein content of milk replacers appears to determine the digestibility both of protein and of other nutrients (Henning, 1982). From a physiological point of view, this fact may arise from the effect that the protein concentration has on the nature of the abomasal coagulum, especially when the protein is of lactic origin. This coagulum, formed from protein, fat and $\mathrm{Ca}$ from the feed, gradually releases these nutrients and they enter the small intestine where they are digested and absorbed. The formation of a firm and rubbery coagulum reduces the passage rate of nutrients and allows them to be more completely digested (Radostis \& Bell, 1970; Roy, 1980; Thivend et al. 1980; Sanz Sampelayo et al. $1990 \mathrm{a}$ ). It has also been suggested that the digestibility of the nutrients contained in milk replacers depends on their level of intake, because the amount of pancreatic juice secreted and its enzyme content increase with the amounts of protein and fat which remain undigested on arrival at the duodenum (Ternouth et al. 1974, 1975). The results obtained in the present study are in keeping with the previously-mentioned observations. Thus it is suggested that the improved digestibilities obtained when diets with a high protein concentration were used result from the nature of the abomasal coagulum formed and the greater amounts ingested. In addition, our results indicate that the DE and $\mathrm{ME}$ concentrations of the milk replacers increase as their fat concentration increases due to the increasing gross energy concentration of the corresponding diets, even though a high fat concentration in the milk replacers appears to decrease the values for energy digestibility and metabolizability. The effect of protein and fat concentrations of the milk replacers on the energy metabolizability and ME concentration of the diets undoubtedly reflects the effect that these dietary components have on the energy digestibility and DE concentration of the diets. For all diets, $95-96 \%$ of the DE was metabolizable.

The DM or ME intake increased as the protein concentration of the milk replacers increased. This can be explained, in the first instance, by the significant effect that the protein concentration has on the digestibility. It is well recognized that the more digestible the diet, the greater its intake. However, as has been mentioned previously, the amounts of milk replacers consumed can influence their digestibility. In other words, it is suggested that the replacers with the highest protein concentration have a higher digestibility as a result of the nature of the abomasal coagulum formed and that this in turn leads to a higher intake, which leads to greater secretion of pancreatic juice rich in enzymes enhancing the digestibility and, thus, once again stimulating the consumption of more feed. Other mechanisms whereby protein concentration may influence feed intake are considered in the next section.

\section{$D M$ and $M E$ intake as affected by feed composition}

Information is scarce on the dietary factors affecting the voluntary feed intake of preruminant animals, although the few studies available seem to indicate that, while during the first 2 weeks of life the size of the abomasum may be the primary regulatory factor of feed intake, between the second and third weeks of life the amount of feed consumed is a function of the amount of energy ingested (Ternouth et al. 1985; Lara, 1991), there being glucostatic and lipostatic controls which function so as to maintain an adequate energy balance (Boda et al. 1984). With respect to what generally appears to occur in the growing animal, Webster (1986) has demonstrated that by varying the diet composition it is possible to vary the body composition, indicating that the animal has certain goals with respect to body composition and varies its intake of certain diets in order to get as close to these goals as possible. In this regard, Radcliffe \& Webster $(1978,1979)$ feeding lean and obese rats 
with diets differing in their protein concentrations found that the intake of the low-protein diet was lower than that of higher-protein diets. This finding they interpreted as indicating that in both lean and obese rats during growth, feed intake is efficiently regulated with the aim of achieving the best rates of protein retention possible.

When diets whose protein concentrations do not allow this are offered, the control of feed intake does not operate by increasing consumption of the diet so as to obtain greater protein intake and better growth, but rather induces consumption of only a sufficient amount to obtain enough $\mathrm{ME}$ for the limited growth rate permitted by the protein concentration of the diet. Furthermore, and as Forbes (1986) has indicated, there is never one single factor controlling feed intake. The administration of diets with increasing protein concentrations could lead to progressively higher energy intakes, the amount necessary to achieve the maximum possible protein retention being exceeded each time. The excess energy will be deposited as fat and, therefore, not only will an increasing protein concentration in the diet lead to higher growth, but it will also lead to a different body composition. In addition, Harris et al. (1988), using the same type of animals as Radcliffe \& Webster $(1978,1979)$, and employing diets with different DP and DE concentrations, obtained results that led them to conclude that it is the amount of energy ingested that determines the maximum feed intake of the animals, while the protein concentration of the diets has no effect. However, despite this conclusion, it should be pointed out that in one of the trials conducted by Harris et al. (1988), in which lead animals were used, while the amount of energy ingested did not change in any statistically significant way with the concentration of protein in the diet, it did show an increase up to a certain protein level, after which it fell.

A possible cause of the discrepancy between the results of Harris et al. (1988) and Radcliffe \& Webster $(1978,1979)$ may be the difference in the age of the animals used by each group. In both trials the feed intake was expressed as amount per animal and the size of the animals in question was not taken into account. The results obtained in the present report seem to confirm the findings of Radcliffe \& Webster $(1978,1979)$ and Webster $(1986)$ that the amount of ME consumed by the kid goat depends on the DP concentration of the diets, increasing up to a maximum value as the DP concentration of the diet increases. As Parks (1982) reported, different animal life processes show this same geometrical feature of increasing with diminishing slope and becoming asymptotic to a maximum value of the independent variable.

Together with this, and according to the established relationships between DM or ME intake and DP concentration of the diet, it is assumed that at zero DP concentration, DM or ME intake will also be zero. From a nutritional point of view it is not difficult to suppose that the level of intake of a diet without protein will be, on principle, very low in any animal for its first period of life and it will soon be rejected. Forbes (1986), analysing the principal dietary factors affecting voluntary feed intake, reported that this is depressed by diets of low protein concentration which lead eventually to death.

From the relationship established between the DM or ME intakes and the DP concentration of the diet, we can estimate the DP concentration at which ME intake would be greatest. This can be obtained from the corresponding first derivative equation once this has been made equal to zero and the DP value that satisfies it has been calculated. As the ME concentration of the DM for each milk replacer was different because of the effect of both protein and fat concentrations of the milk replacers on their ME concentration, it was considered more correct to estimate the DP concentration at which feed intake would be greatest, from the relationship established between ME intake and DP concentration of the diet. The resulting value is $327 \mathrm{~g} / \mathrm{kg}$ DM. Once this value has been calculated, and having deduced from this study that the DP concentration is determined by the corresponding 
concentration of crude protein, the general relationship existing between the crude protein concentration and the DP concentration will enable us to estimate the amount of crude protein at which ME intake would be greatest. The relationship between the DP (g/kg DM) concentration and the crude protein $(\mathrm{CP} ; \mathrm{g} / \mathrm{kg} \mathrm{DM})$ concentration is given by the equation:

$$
\mathrm{DP}=0.734(\text { SE } 0.029) \mathrm{CP}+0.0006(\mathrm{SE} 0.0001) \mathrm{CP}^{2}
$$

$\left(R^{2} 0 \cdot 998 ;\right.$ RSD 9.09).

For a DP content of $327 \mathrm{~g} / \mathrm{kg}$ DM, the crude protein concentration is $347 \mathrm{~g} / \mathrm{kg} \mathrm{DM}$. These values exceed the maximum concentrations studied in the present experiment and therefore require further verification.

\section{Empty-body weights, their composition, and protein and fat deposition rates}

For any species and for its first period of growth, the dietary factor that most clearly determines growth rate is the protein concentration of the feed, due to its stimulating effect on protein retention; this increase in live weight results in part from the water which is deposited with the protein. In pre-ruminant animals during growth there is little change in the protein concentration of the weight gains, although the fat deposits increase and the amount of water diminishes (Vermorel, 1975; Jagusch et al. 1983; Bas \& Morand-Fehr, 1987; Sanz Sampelayo et al. 1990 b). Furthermore, Vermorel et al. (1979) reported that in calves a higher $\mathrm{ME}$ intake results in higher protein retention and fat deposition. Blaxter (1964) studied the quantities of protein and fat retained with different milk intakes in similar animals and obtained an asymptotic response for protein retention and an exponential one for fat deposition.

The low voluntary feed intake of the pre-ruminant kid goat means that during the first $30 \mathrm{~d}$ of its life its body composition is only related to its live weight, independently of intake level and dietary regimen (Sanz Sampelayo et al. 1990 b). For older or heavier animals, in order to obtain more fatty carcasses, different breeds of goat, or milk replacers with increasing fat concentrations have been used. This has given rise to changes in body composition, but these changes have always been less than expected (Bas \& Morand-Fehr, 1987; Bas et al. 1987, 1992; Lara, 1991). Lara (1991) attributed this low response primarily to the low voluntary feed intake of the animals used, pointing out the necessity to investigate in these animals the dietary factors affecting their voluntary feed intake. The results obtained in the present study would seem to support these findings and opinions. First, the protein concentration of milk replacers affected the empty-body weight reached. At the same time, ME intake, which was itself affected by the protein concentration of the milk replacers, also influenced the empty-body composition (amount of DM, fat and energy concentrations expressed on the basis of empty-body weight) and protein and fat deposition rates. Similarly it can be concluded that DP concentration of the diet influenced empty-body composition and protein and fat deposition directly. In addition it had indirect effects by its influence on ME intake which was related to the empty-body composition and protein and fat deposition. It appears that empty-body DM and energy concentrations as well as protein deposition rate increase with increasing DP concentration of the diet up to a maximum concentration. In contrast, linear relations were established between emptybody fat concentration or fat deposition rate and the DP concentration of the diet. These results are in general agreement with those obtained by Blaxter (1964) for calves fed on different milk intakes.

In summary, and in agreement with the observations of Radcliffe \& Webster $(1978,1979)$ and Webster (1986), during growth the kid goat appears to regulate its feed intake in order to satisfy its ME requirements, these depending on the DP concentration of the diet. As the 
concentration of DP increases, the ingestion of ME also increases so that together with an increased growth rate there is also an increased deposition of fat. This process ends when the protein retention capacity of the animal is reached. For the kid goat, a lean animal, it is calculated that this point is reached at a relatively high concentration of DP or crude protein in the diet, $327 \mathrm{~g} / \mathrm{kg} \mathrm{DM}$ or $347 \mathrm{~g} / \mathrm{kg}$ DM respectively.

This study was supported financially by the Interministerial Commission of Science and Technology (Spain) (Project GAN90-0781). We are grateful to M. P. Sanz Sampelayo for her technical assistance with regard to statistical analysis.

\section{REFERENCES}

Aziz, M. A. \& Sharaby, M. A. (1993). Collinearity as a problem in predicting body weight from body dimensions of Najdi sheep in Saudi Arabia. Small Ruminant Research 12, 117-124.

Bas, P. \& Morand-Fehr, P. (1987). Effect of goat milk or milk replacer intake on growth and carcass quality of kids. In Proceedings of the IV International Conference on Goats, vol. 2, 1470. Brasilia: EMBRAPA.

Bas, P., Morand-Fehr, P., Schmidely, P. \& Hervieu, J. (1987). Effect of dietary lipid supplementation on pre- and post-weaning growth and fat deposition in kids. Annales de Zootechnie 36, 339.

Bas, P., Schmidely, P., Morand-Fehr, P., Rouzeau, A. \& Hervieu, J. (1992). Effect of level of energy intake on body composition in milk fed kids. Proceedings of the Meeting of the Subnetwork Nutrition. FAO Network of Cooperative Research on Sheep and Goats, p. 41 [J. E. Lindberg, editor]. Uppsala: Swedish University of Agricultural Science.

Blaxter, K. L. (1964). Los procesos productivos (The productive processes). In Metabolismo Energético de los Rumiantes, pp. 159-175 [K. L. Blaxter, editor]. Zaragoza: Acribia.

Boda, K., Koppel, J., Kuchar, S. \& Kozes, S. (1984). Food intake control in suckling lambs. Canadian Journal of Animal Science 64, Suppl., 318-319.

Forbes, J. M. (1986). Dietary factors affecting intake. In The Voluntary Food Intake of Farm Animals, pp. 86-113 [J. M. Forbes, editor]. London: Butterworths.

Harris, R. B. S., Tobin, G. \& Hervey, G. R. (1988). Voluntary feed intake of lean and obese Zucker rats in relation to dietary energy and nitrogen content. Journal of Nutrition 118, 503-514.

Havrevoll, O., Hadjipanayiotu, M., Sanz Sampelayo, M. R., Nitzan, Z. \& Schmidely, P. (1991). Milk feeding systems of young goats. In Goat Nutrition pp. 259-270 [P. Morand-Fehr, editor]. Wageningen: Pudoc.

Henning, W. P. (1982). High fat whey powder in calf milk replacer. The role of protein/energy ratios. South African Journal of Animal Science 12, 15-20.

Jagusch, K. T., Duganzi, D. M., Kidd, G. T. \& Church, S. M. (1983). Efficiency of goat milk utilization by milkfed kids. New Zealand Journal of Agriculture Research 26, 443-445.

Lara, L. (1991). Factores nutritivos y metabólicos que determinane el crecimiento y desarrollo del ganado caprino y ovino prerrumiante. Lactancia artificial (Nutritional and metabolic factors affecting the growth and development of pre-ruminant kid goats and lambs: artificial rearing). PhD Thesis. University of Granada, Spain.

Morand-Fehr, P., Bas, P., Rouzeau, A. \& Hervieu, J. (1985). Development and characteristics of adipose deposits in male kids during growth from birth to weaning. Animal Production 41, 349-357.

Moulin, P. (1983). Les corps gras animaux dans les aliments d'allaitement (Animal fats in milk replacers). Revue Française des Corps Gras 30, 287-290.

Ørskov, E. R. (1982). Physiology of the ruminant stomach. Pre-ruminant nutrition. In Protein Nutrition in Ruminants, pp. 1-8 [E. R. Ørskov, editor]. London: Academic Press.

Parks, J. R. (1982). Ad libitum feeding and growth functions. In A Theory of Feeding and Growth of Animals, pp. 25-37 [J. R. Parks, editor]. Berlin: Springer-Verlag.

Patureau-Mirand, P. (1975). Quelques aspects de la nutrition azotée du veau et de l'agneau préruminants (Different aspects of nitrogen nutrition azotée du veau et de l'agneau prérruminants (Different aspects of nitrogen nutrition in the pre-ruminant calf and lamb). Les Industries de P'Alimentation Animale 1, 27-41.

Pearson, D. (1976). Milk products. In Laboratory Techniques in Food Analysis, pp. 145-147 [D. Pearson, editor]. London: Butterworths.

Radcliffe, J. D. \& Webster, A. J. F. (1978). Sex, body composition and regulation of food intake during growth in the Zucker rat. British Journal of Nutrition 39, 483-492.

Radcliffe, J. D. \& Webster, A. J. F. (1979). The effect of varying the quality of dietary protein and energy on food intake and growth in the Zucker rat. British Journal of Nutrition 41, 111-124.

Radostis, O. M. \& Bell, J. M. (1970). Nutrition of the pre-ruminant dairy calf with special reference to the digestion and absorption of nutrients. A review. Canadian Journal of Animal Science 50, 405452.

Roy, J. H. B. (1980). The Calf. London; Butterworths. 
Ruiz Mariscal, 1., Gomez, A., Prieto, I., Sanz Sampelayo, M. R., Gil, F. \& Boza, J. (1990). Nota sobre el diseño y análisis de un sistema de alimentación continuada para el cabrito lactante. (Note on the design and evaluation of a system for ad libitum feeding of the milk-fed goat kid). Investigación Agraria. Pruducción y Sanidad Animales 5, 43-50.

Sanz Sampelayo, M. R., Muñoz, F. J., Anguita, T., Lara, L., Gil, F. \& Boza, J. (1987). Utilización de calcio y fósforo por el cabrito de raza Granadina. Alimentación exclusivamente láctea (Calcium and phosphorus utilization by the milk-fed kid goat of the Granadina breed). Investigación Agraria. Producción y Sanidad Animales 2, 163-172.

Sanz Sampelayo, M. R., Hernández-Clua, O. D., Naranjon, J. A., Gil, F. \& Boza, J. (1990a). Utilization of goat milk vs milk replacer for Granadina goat kids. Small Ruminant Research 3, 37-46.

Sanz Sampelayo, M. R., Ruiz, I., Gil, F. \& Boza, J. (1990b). Body composition of goat kids during sucking. Voluntary feed intake. British Journal of Nutrition 64, 611-617.

Soliman, H. S., Ørskov, E. R., Atkinson, T. \& Smart, R. I. (1979). Utilization of partially hydrolysed starch in milk replacers by newborn lambs. Journal of Agricultural Sciences, Cambridge 92, 343-349.

Statgraphics (1991). User manual: Statistical Graphics System by Statistical Graphics Corporation. Rock-Ville, Maryland, USA.

Steel, R. G. D. \& Torrie, J. H. (1984). Principles and Procedures of Statistics. A Biometrical Approach, 2 nd ed. Singapore: McGraw-Hill Inc.

Ternouth, J. H., Roy, J. H. B. \& Siddons, R. C. (1974). Concurrent studies of the flow of digesta in the duodenum and of exocrine pancreatic secretion of calves. 2. The effects of addition of fat to skim milk and of severe preheating treatment of spray-dried skim-milk powder. British Journal of Nutrition 31, 13-26.

Ternouth, J. H., Roy, J. H. B., Thompson, S. Y., Toothill, J. \& Gillies, C. M. (1975). Concurrent studies of the flow of digesta in the duodenum and of exocrine pancreatic secretion of calves. 3 . Further studies on the addition of fat to skim milk and use of non-milk proteins in milk-substitute diets. British Journal of Nutrition 33, 181-196.

Ternouth, J. H., Stobo, I. J. F., Roy, J. H. B. \& Beattie, A. W. (1985). The effect of milk substitute concentration upon the intake, digestion and growth of calves. Animal Production 41, 151-159.

Thivend, P., Toulec, R.\& Guilloteau, P. (1980). Digestive adaptation in the pre-ruminant. In Digestive Physiology and Metabolism in Ruminants, pp. 561-585 [Y. Ruckebusch and P. Thivend, editors]. Lancaster: MTP Press.

Vermorel, M. (1975). Le métabolisme énergétique du veau et de l'agneau préruminant (The energy metabolism of pre-ruminant calf and lamb). Les Industries de l'Alimentation Animale 1, 9-26.

Vermorel, M., Bouvier, J. C. \& Geay, Y. (1979). Energy utilization by growing calves: effects of age, milk intake and feeding level. In Energy Metabolism of Farm Animals, pp. 49-53 [L. E. Mount, editor]. London: Butterworths.

Walker, D. M. (1973). Amino-acid imbalance and its effect on energy utilization in the milk-fed lamb. In Energy Metabolism of Farm Animals, pp. 75-78 [H. H. Menke, H. J. Lanztsch and J. R. Reichl, editors]. Stuttgart: Universität Hohemheim.

Walker, D. M. (1986). Body composition of animals during sucking and the immediate post-weaning period. Proceedings of the Nutrition Society 45, 81-89.

Webster, A. J. F. (1986). Factors affecting the body composition of growing and adult animals. Proceedings of the Nutrition Society 45, 45-53.

Williams, A. P. \& Hewitt, D. (1979). The amino acid requirements of the preruminant calf. British Journal of Nutrition 41, 311-319. 